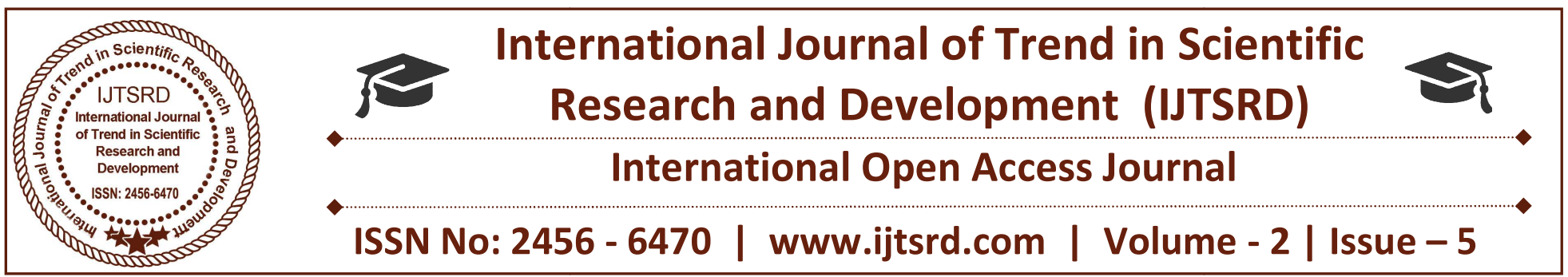

\title{
Karma: A Concept or A Precept
}

\author{
Rojalin Swain \\ Research Scholar, Visva-Bharati, University, Shantiniketan, West Bengal, India \\ Lecturer, Nilamani Mahavidyalaya, Balasore, Odisha, India
}

\section{ABSTRACT}

Really! Lord's creation is amazing. Isn't it? The creations includes both Jivas and Ajivas. Jivas are those living beings which have Prōṇa inherently present in them. Ajivas are those beings which have no Prōna. Jivas are classified as animals, insects, bees, birds etc. But out of them Humans is the most auspicious creation of God. All others Jivas are backed by instincts except humans. For examplesometimes we see in road, sheep are gathered in one place, but if one of them goes one side, all other sheep shall follow them. They have no thinking capacity. But Man is guided by reason. He ought the thinking capacity to what to do or what ought not to do. Because he give emphasised on reason to do specific action. So, action has the meaning only in respect of human. Action is required to develop one's social, economical, psychological, political, logical needs. Action is needed in every field of life to live and maintain perfect harmony with yourself as well as others. Here, attempts have been made to discover the three issues of this paper: first, the relation of karma with past, present and future. Secondly. the meaning of karma in human life. thirdly, the justification of action in society. However this paper tries to unveil the necessity of action in relation to man and society.

Keynote: kartō, Vidhōna, daiva, paurușa, mōnușa, distambaliyah

\section{INTRODUCTION}

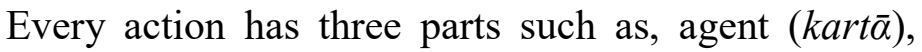
action (karma), consequence (karmaphala). If there are different options to choose an action, then kart $\bar{\alpha}$ opt an action according to his choice. All action is purpose pointed. Action is the 'means' through which one can get the 'end'. Man has the right to opt but he has no control over his consequences. For example- a Person is always conscious regarding his health but he is always under sick. Karmic order is under the control of causal order. So there is saying 'As you sow, so shall you reap'. 'As is your giving, so is your returning'. So one is covered by the boundary to enjoy or suffer the consequences of his karma.

Kart $\bar{\alpha}$ is that person who is doing some work. We can differentiate an agent from another person for his action or doing only. There is difference between doing and being. 'The notion of kart $\bar{\alpha}$ is a functional notion.' ' doing' means ' what one do' and 'being' means 'what one is'. Kart $\bar{\alpha}$ is introspectively associated with karma. Performing without action is not possible and action without performing is not possible. There is no sense of kart $\bar{\alpha}$ without karma. kart $\bar{\alpha}$ is always active to act. kart $\bar{\alpha}$ has no relation with a-karma. So performing can be said to be the benchmark of its suitability and comprehensibility. So an individual have to exist for doing an action. To be is to be exist; to exist to be an agent; to be an agent, one should perform some kind of activity. Survival without executing is feasible but executing without survival is not conceivable. Here there may arise a question, survival without executing is not possible, then what's about the state of deep-sleep of a person, whether to exist or not? The reply is that, the people do exist in that state. We can't say, his body does not exist rather we say, bodily state and deep-sleep are incidentally connected. If kart $\bar{\alpha}$ is lame, then karma is blind. If karma is lame, kart $\bar{\alpha}$ is blind. I mean to say, as lame and blind person are interdependent on each other. Similarly kart $\bar{\alpha}$ and karma are mutually

interdependent. An individual agential quality is not 
his composing and expressive feature. A person is not kart $\bar{\alpha}$ by birth rather they have the inherent potency for becoming an agent after his birth. So it is a functional feature only because of doing an action. An individual becomes an agent only because of the deeds he done.

Karma arises when energy is accomplished and the execution of energy always has to aware endeavour. Unless and until, one expresses his endeavours in practice, nobody can be said to be builds aware endeavours. This can be possible only by performing an action. One's action can make judgement whether one could make cognizant endeavour or not. Action emanate when energies are implemented through action deliberately.

Similarly, to cause is not to act. To cause is to arise or to initiate and or to convey something. "All the cases of causation are not the cases of doing through all the cases of doing are the cases of causation." "For example- salt, has a causal energy to evaporate water. But salt can't be said to be an agent of water evaporation nor water can be said an action of salt. Salt cannot abstain from water's acquiring; it evaporated when certain preceding conditions are present. But an agent has the capacity to choose an action as his desire and abstain himself from not causing action which salt does not have. Salt has no will. Its characteristics are to dissolve in water. But an agent has exercise his will to causing something. The kart $\bar{\alpha}$ can changed the actions as per his wish but salt have no choice without dissolve in water. An action is under the purview of kart $\bar{\alpha}$. So kart $\bar{\alpha}-k a r m a$ relationship is not like salt-water relationship. 'It is telio-causal in nature. The cause has the potency of making but it has no potency of abstaining. So, we can't say that the potency of kart $\bar{\alpha}$ is identical with the potency of cause. For example- the word 'excuse' has no meaning in the context of salt. But it makes significant meaning in the context of an agent. So, here we can't add the word true or false rather it is meaningless because the outside used in the realm of its aptitude has no meaning. The word 'excuse' can make matching with the other words like mistaking, deciding, forgiving, justifying, exempting, releasing, mitigating etc. So action cannot arise without an agent.

\footnotetext{
${ }^{1}$ Karma, dharma\& moksa, conceptual essays on Indian ethics by Jag at Pal, Abhijit Publications, Delhi, 2004,
}

The law of karma advocates "the doer of good gets good result and the doer of bad gets bad result and no doer get reverse result of his action." "2 The concept of karma is conceptually interrelated with the deeds of karma. 'All the basis of consequences (karma-phala) can be the basis of event-phala but all the basis of event-phala cannot be the basis of karma-phala. Karta and karma are inevitable and adequate circumstances for karma-phala to eventuate, which is not legitimate of event - phala. So the phala of an event is not introspectively related with the concept of Karta and karma because it can be established apart from autonomously of karma and Karta because events from where event-phala arises are comprehensible aside from and autonomous of them. Event is related with cause. So the idea of justifiability, liability, and obligation do not make any meaning in the connection of event. For example- a Karta can get his consequences in form of prize of reward and punishment by his action not by any event which is responsible for the notion of reward and punishment approximately. A Karta has the autonomy to choose an action. But he has no autonomy either in conscious or unconscious to choose the consequences, he done. He may attend or may not attend the end. Karma is an action because it does. Karta is an agent because he performed. They are logically grounded with each other.

Karma is also linked with fate. In Matsya Purōna, "there are two destinies (Vidhōna). One is brought about by fate or God (daiva) and the other by men (mōnusa). Fate cannot be fathomed; and so all activity is based upon manly effort (pauruṣa). One's own karma is called fate, earned from another body; therefore wise men say that manly effort is more important. An adverse fate may be overcome by effort, by those who engage in ceremonies and strive to rise. By effort men obtain the fruit that they seek; men who have no manly energy believe in fate. Fate, what a man does, and the effects of the three times (past, present and future) this triad bears fruit for a man." 3 Yyati in Uttaryayati says: "living creatures depend upon fate (dista) and their acts are wasted: regardless of what one obtains, the wise one is not concerned, knowing as he does that his fate is stronger

\footnotetext{
${ }^{2}$ Karma, dharma\& moksa, conceptual essays on Indian ethics by Jag at Pal, Abhijit Publications, Delhi, 2004

${ }^{3}$ Matsya Purōṇa, 221.1-12.
} 
(distambaliyah). Whether it is good or ill-fortune that comes to him, it is not but fate that brings things to pass." 4 Sometime we see undeserved candidate can get good Job than the deserved candidate. It may be due to his fate or may be for past action.

Karma can be classified as Sāttvika, Rōjasika,Tōmasika. Sōttvika karma refers to the satogunas which is clear from all contamination (nirmala) and inadequacy (anōmya) which is buoyant, enlightenment, happiness, pleasure in nature. 'Its colour is white'. Sāttvika food includes spice less food, fruits, and vegetarian foods. This type of food helps one to develop the calmness and equanimity in mind. It also developed the inner peace of mind. This karma also bound to the world, "it produces a state of well-being and intellectual superiority in the person who has attained this state. ${ }^{5}$ Rajjasika karmas refer to rajoguna. Wildness, anger, anxiety, fighting, greediness nature includes in rōjasika karma. This karma involves attachment and desire. Spices food, non-veg item includes rōjasika karma. 'Its colour is red.' It makes human beings attached to karmas or worldly activities. ${ }^{6}$ Tāmasika karma refers to tamoguna, which develops slothness, confusion, laziness, inactiveness in nature. 'Its colour is dark'. Tea, coffee, smoking, alcohol includes tōmasika karmas. 'tōmasika karmas are born of absence of discrimination $\quad(\operatorname{pram} \bar{\alpha} d a)$ indolence and somnolence. 7

Prakrti consists of these three guna which is inherently present in all living being. We can point out the nature of a man by this three gunas. An agent can performed all activities by these three gunas. According to these gunas, judged a person by these three gunas and get the consequences according to the action done by him. "The sāttvika person goes to the upper worlds (heavens), the rājasika persons are born in the middle world (the world of men) and the tōmasika persons are reborn in lowly existence (birds, beasts and insects)." and as is the man, so is his birth. As is the birth, so is his destiny. There is a description In Hitopadeśa, 'whatsoever be the deed done, good or bad by oneself and its cause, the manner in which it has been done,

\footnotetext{
4 Uttaryayati, 1, 84, 6-8.

${ }^{5} \mathrm{BG}, 14,5,6$ and 9 ,

${ }^{6} \mathrm{BG}, 14,7$ and 9 ,

${ }^{7} \mathrm{BG}, 14,8$ and9,

${ }^{8} \mathrm{BG}, 14,18$,
}

the time and place at which it was done and the duration thereof, its doer will bear its consequences from the same cause, in the same manner, at the same time and place and for the same duration.' So karma will affect time, place and duration also. This time may be for short term or long term. It will bear its fruit at the right time will reach. In the story, "Queen Mallika and Her Dog", 9 ibid, XI.6, it is stated that after her death Mallika, the queen is tormented in hell for 7 days as a punishment for the sin of bestiality, for making a false statement to her husband and also for making a false accusation of bestiality against him. Subsequently she was reborn in the Tūsita heaven as a reward for her good deeds. "All things have 'be causes', was described by Arthur Koestler in his book, 'Act of creation'.

H.P. Blavatsky said, 'karma has not involved its decrees in darkness purposely to perplex man, nor shall it punish him who dares to scrutinize its mysteries. On the contrary, he who unveils through study and meditation its intricate paths and throw light on those dark ways, in the windings of which so many perish owing to their ignorance of the labyrinth of life, is working for the good of his fellowmen'.

Karma has an effect on the individual's character also. Character is the totality of biases, which is the propensity of the mind. 'Good' and 'Bad' reflects in one's own character. Mind constitutes the vast knowledge of library of the world. Man is the core of the universe. Happiness, sorrow, evil activities, good, right, wrong makes sense only in human domain. Anything you can judge by the character of man. What we see in the world like the actions, movement in society that are the reflection of contemplation, the demonstration of the volition of man. Determination is generated by character and character is assembled by karma. Our actions ascertain what we earn and what we can comprehend. For example- the parents may earn more money. They will give all the comforts, fulfil the necessity of their child and deserves that their children may get a good future but they don't because their children were unable to get a job, unable to deserve the candidature. This deserving is made by one's action, what their children is not doing. We are answerable to what we are and no matter what we desire ourselves to be, we have the potency or capability to do that. Needless to say, all

\footnotetext{
${ }^{9}$ Arthur Koestler, Act Of Creation, New York. The Maclilian co., 1964, p.616.
} 
action is aroused by the potency of mind. One has to awaken the soul because the potency is in inside the man. To knowing, willing, becoming are come within the inherent potency of man. So one has to wake up to assimilate and coordinate the works to proper place, time and situation.

An individual can works with various motives. Some persons want name, fame, money, power, position and they work for the same. Today, we see that man is very selfish in nature. He can work for him only. But still there are some persons who can 'work for the sake of work only'. If we take an example of Gandhi, he had to take more struggle and challenges to give the independence to India. He can work for others, not for him. The mass of us cannot behold after a few years. They have no patience and they have no interest to take it in practice, so that immortality became raised. This is our worthlessness, our incapability.

'Each is great in his own place'. Every person made of different models. All the persons are made of different looks, different bodies, different ability, different opinions, and different destiny also. Let everybody act the best he can for apprehending his own standard. It is not right to say, I can judged another person's situations from the viewpoints of my mind. Individuality in varieties' is the law of creation. We do not pass any comment to others for their standards. For example- some persons thinks that Green grocers are lower standard people and poor. They also pass comments to their children like, he is the son or daughter of green grocer, and they do not get sufficient foods to eat or like that. But they forget that if that person does not sell vegetables and fruits then what they eat? Where the vegetables are available? From whom, we buy the vegetables? Without food we may die. But no one will go to the root cause of problem. So everyone is big in his own place. Our duty is to inspire others in his struggle to live up according to his own standards and endeavour at the same time to make the norms as near as possible to the truth.

Every man has to cross across by four stages of life like, Brahmacharya, Grōhystha, Vōnaprastha and Sannyōsa. Self-control is the key note of brahmacharya. In this stage, one can maintain discipline in mind, spirit and body. So, one can attain the destiny. One can practice self-regulation. One can play householder role in Grōhyastha stage. In this stage man and woman marry together and share thoughts and cooperate with each other to attained purusart has (Dharma, Artha, Kōma, Mokșa). In this stage one should performed duties to his forefathers, ancestors, children, and parents. In Vōnaprastha stage, one should detach from the worldly desires and works for renunciation. One should concentrate more on spiritual aspect of life. In Sannyōsa stage, one should detach from his family and do work for the welfare of the whole humanity. He has no desire to wish anything nor worried for his death. So, 'the duty of the one is not the duty of the other'. Last, but not least, SrimadBhagvadgit $\bar{\alpha}$ hold the point,

\section{1. 'Karmanyevōdhik $\bar{\alpha}$ raste m $\bar{\alpha}$ phaleșu kadōcana}

2. M $\bar{\alpha}$ karmaphalaheturbhūr $m \bar{\alpha}$ te sañgo' stvakarmani.'

This verse indicates, our right is to do work and perform duties rightfully. We have no right to acquire the fruit as per our desire. Let not the consequences of action be your inducement, nor let your appendage be to inaction. So one should be a Niskōma karmi, everything should be surrender to Him (Supreme).

\section{Conclusion: -}

So, karma is neither a concept nor a precept rather it is the necessity because it is only karma, which is the cause of birth and death. It is only the karma which helps one to attained emancipation. It is only the karma which is related to past, present and future. It is only the karma which gives the perfect result of the consequences. It is only the karma which is the binding force of man to the world. It is right that, 'man is the maker of his destiny', similarly man is the producer, director, actor and villain of his karma also. We don't see our past, but some unseen power is seen all things. The supreme can judge the action, what one done. So one must keep in the mind 'as you sow, so shall you reap' and 'as is your done, so is your result'. So without karma, one can't exist in this universe. Karma is in your hand, so does it thoughtfully and mind fully. So that, one will get a good future,

\section{REFERENCES}

1. N.C. Padhi, Karma and Freedom, a conceptual and critical exploration, published by $\mathrm{M} / \mathrm{s}$ Upagupta Publications, Gosaninuagam, Berhampur-760003, 1986.

2. Prabha Duneja, the Holy Geeta, Rp Jain for New Age Books, New Delhi, 2014. 
International Journal of Trend in Scientific Research and Development (IJTSRD) ISSN: 2456-6470

3. R.K. Gupta, Social Action and Non-Violence, Indian Council of Philosophical Research, New Delhi, 1995.

4. Swami Muni Narayan Prasad, Karma and Reincarnation (The Vedantic Perspective), published by D.K. Print world (p) Ltd, 1994.

5. Swami Vivekananda, Karma yoga, Deepak Publications, 2016.
6. Yuvraj Krishan, the Doctrine of Karma, Motilal Banarsidass Publishers Private Limited, Delhi, 1997.

7. V. Hanson, R. Stewart \& S. Nicholson, Karma, Rhythmic Return to Harmony, Motilal Banarsidass Publishers Private Limited, 2001.

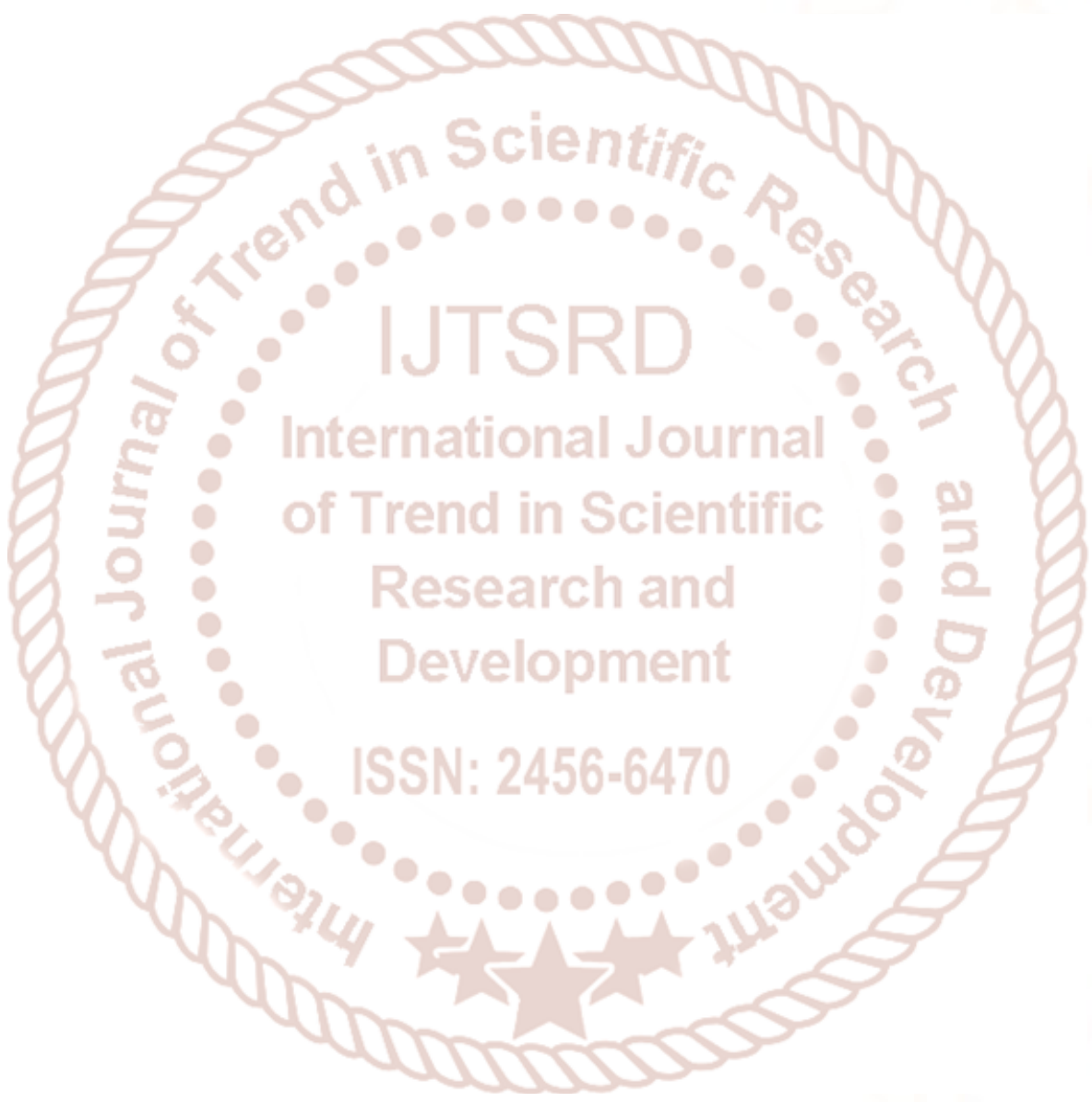

